\title{
Augmented hydrolysis of acid pretreated sugarcane bagasse by PEG 6000 addition: A case study of Cellic
}

\section{CTec2 with recycling and reuse}

\section{Pratibha Baral $^{\mathrm{a}}$, Lavika Jain ${ }^{\mathrm{a}, \mathrm{b}}$, Akhilesh Kumar Kurmi ${ }^{\mathrm{a}}$, Vinod Kumar ${ }^{\mathrm{c}}$ and Deepti Agrawala,b*}

${ }^{a}$ Biochemistry and Biotechnology Area, Materials Resource Efficiency Division, CSIR- Indian Institute of Petroleum, Mohkampur, Dehradun-248005, India

bAcademy of Scientific and Innovative Research (AcSIR), CSIR-HRDC Campus, Ghaziabad 201002, India 'Bioenergy and Resource Management Centre, School of Water, Energy and Environment, Cranfield University, Cranfield MK43 0AL, UK

*Corresponding author: Tel: +91-135-2525763

Email address: deepti@iip.res.in; Orcid ID: $\underline{\text { 0000-0002-6224-3580 }}$

\begin{abstract}
In an integrated lignocellulosic biorefinery, the cost associated with the "cellulases" and "longer duration of cellulose hydrolysis" represents the two most important bottlenecks. Thus to overcome these barriers, the present study aimed towards augmented hydrolysis of acid pretreated sugarcane bagasse within a short span of 16h using Cellic CTec2 by addition of PEG 6000. Addition of this surfactant not only enhanced glucose release by two fold within stipulated time, but aided in recovery of Cellic CTec2 which was further recycled and reused for second round of saccharification.

During first round of hydrolysis, when Cellic CTec2 was loaded at 25mg protein /g cellulose content, it resulted in $76.24 \pm 2.18 \%$ saccharification with a protein recovery of $58.4 \pm 1.09 \%$. Filtration through $50 \mathrm{KDa}$ PES membrane retained $\sim 89 \%$ protein in 4.5 fold concentrated form and lead to simultaneous fractionation of $\sim 70 \%$ glucose in the permeate.

Later, the saccharification potential of recycled Cellic CTec2 was assessed for the second round of saccharification using two different approaches. Unfortified enzyme effectively hydrolysed $67 \%$ cellulose whereas $72 \%$ glucose release was observed with Cellic CTec2 fortified with $25 \%$ fresh protein top-up. Incorporating the use of the recycled enzyme in two-stage hydrolysis could effectively reduce the Cellic CTec2 loading from 25 to $16.8 \mathrm{mg}$ protein/g cellulose.

Further, $80 \%$ ethanol conversion efficiencies were achieved when glucose-rich permeate obtained after the first and second rounds of saccharification were evaluated using Saccharomyces cerevisiae MTCC 180.
\end{abstract}

Keywords: Cellic CTec2; PEG 6000; PES membrane filter; recycling; saccharification 


\section{Introduction}

In the global energy mix, the importance and choice of second generation $(2 \mathrm{G})$ feed stock especially for biofuel applications supersedes first-generation $(1 \mathrm{G})$ feedstock due to numerous reasons such as their renewable nature, no controversy on food $v s$ fuel, lesser green house gas (GHG) emissions, cheap and abundant supply, effective land usage etc. [1]. However, it is essential that lignocellulosic biofuels must meet or exceed in economic performance as well, besides environmental and energy balance criteria, when compared to $1 \mathrm{G}$ biofuels. The comprehensive review by Lynd et al. confirms that the major roadblock in the wider acceptance and popularity of $2 \mathrm{G}$ biofuels in spite of their commercial take-off lies with the conversion technologies rather than the issue of feedstock selection and its logistics [2].

The recalcitrant features associated with the lignocellulosic feedstock not only significantly enhance the overall cost of the upstream processing such as pretreatment and hydrolysis of the cellulosic fraction to fermentable sugars, but also affect the downstream processing which principally involves valorization of fermentable sugars to fuels and chemicals.

In the upstream processing, the hydrolysis of cellulosic fraction involves the use of cellulase cocktail, a key bottleneck to the process. Several strategies have been employed in the state of the art, for reducing the overall cost of the cellulases by either developing novel enzyme cocktails [3], improvising pretreatment methods for high solid loadings [4], screening for low lignin binding enzymes [5,6], recycling and reusing the enzymes [7,8], enhanced saccharification using surfactants and proteins [9-12] or bioprospecting new microbes capable of consolidated bioprocessing [13].

Recycling of the enzymes is one of the most popular strategies for reducing the overall cost economics of cellulases. Comprehensive reviews on importance of cellulase recycling highlight various strategies that can be integrated in modern biorefineries such as enzyme immobilization, use of filtration membranes, lignin blocking additives, change of temperature and $\mathrm{pH}$, re-adsorption on fresh substrate, recycling of solid and liquid fraction after saccharification etc. $[14,15]$. However, Jørgensen and Pinelo have further emphasized on the two most critical factors that adjudge the successful implementation of this method, one being the relative affinity of the enzymes for solid and liquid during adsorption/desorption processes and other being their stability (temperature, $\mathrm{pH}$, end product inhibition, and lignin) during longer durations of enzymatic saccharification [15].

In the present study, an attempt was made to overcome both the shortcomings addressed in the preceding paragraph. An innovative approach towards augmented hydrolysis of acid pretreated sugarcane bagasse (SCB) was undertaken aided by PEG 6000 aided with a commercial enzyme preparation namely Cellic CTec 2 . In the 
said investigation targeted optimum hydrolysis within a shorter incubation time along with efficient enzyme desorption as observed in our earlier studies [9]. Later the desorbed or free Cellic CTec2 enzyme in the saccharified broth was concentrated using $50 \mathrm{kDa}$ polyether sulfone (PES) membrane and recycled back for second round of saccharification.

The second round of saccharification was designed, considering two different approaches, one wherein no fresh enzyme protein was added and other wherein $25 \%$ fresh enzyme protein loading was done. This approach enabled us to understand whether the addition of $25 \%$ fresh enzyme protein was inevitable or the recycled Cellic CTec2 in standalone mode was able to work with equal efficacy. The glucose-rich permeates obtained after $50 \mathrm{kDa}$ filtration were subjected to ethanol fermentation studies using Saccharomyces cerevisiae MTCC 180, to further evaluate their ability for direct usage as a source of fermentable sugars for the production of biofuels and chemicals.

\section{Materials and methods}

\section{Enzyme and its protein determination}

Cellic ${ }^{\circ}$ CTec2 was kindly gifted by Novozymes A/S (Bagsværd, Denmark). All the chemicals and media components were either procured from Sigma Aldrich, USA or Hi-Media Laboratories (Mumbai, India) and were of analytical or laboratory grade. The protein concentration of Cellic CTec 2 was measured by the Bradford assay using bovine serum albumin (BSA) Fraction V as the protein standard [16]. The protein content of Cellic CTec2 was found to be $99.75 \pm 1.25 \mathrm{mg}$ BSA equivalents/g of the enzyme. The cellulase activity of this commercial enzyme preparation was found to be $127.5 \pm 4.6 \mathrm{FPU} / \mathrm{g}$.

\section{Dilute acid pretreatment of sugarcane bagasse and its compositional analysis}

Raw sugarcane bagasse (SCB) was kindly provided by Dhampur Sugar Mills, India. Before enzymatic saccharification studies, raw SCB was subjected to pretreatment with dilute sulfuric acid $(1.25 \% \mathrm{v} / \mathrm{v})$ at $140^{\circ} \mathrm{C}$ (holding time of $90 \mathrm{~min}$ ) with solid: liquid ratio being 1:8, by the method described previously [17]. The compositional analysis of the acid pretreated SCB was carried out as per the method of National Renewable Energy Laboratory (NREL) described by Sluiter et al [18]. The acid pretreated SCB consisted of 55.14 $\pm 1.2 \%$ cellulose, $2.92 \pm 0.01 \%$ xylan and $33.73 \pm 0.21 \%$ acid insoluble lignin (AISL) content.

\section{Determining optimal pH, temperature and dosage of PEG 6000 for Cellic CTec2}

Conducive conditions of $\mathrm{pH}$ and temperature for enzymatic saccharification were deduced by performing hydrolysis of acid pretreated SCB with Cellic CTec2 enzyme at different pH's in the range of 4-6 with an interval of 0.5 units followed by incubation at different temperatures ranging from $45-60^{\circ} \mathrm{C}$ at an interval of 
$5^{\circ} \mathrm{C}$. All these studies were carried out by addition PEG 6000 at concentration of $0.3 \mathrm{~g} / \mathrm{g}$ AISL content, $7.5 \%$ substrate concentration and enzyme loading of $25 \mathrm{mg}$ protein/g cellulose content, based on our previous results [9].

Once the $\mathrm{pH}$ and temperature optimum for Cellic CTec2 was inferred, optimum dosage of PEG 6000 was deciphered by its addition in the range of $0.1 \mathrm{~g}-0.5 \mathrm{~g} / \mathrm{g}$ AISL content. The duration of this experiment was reduced from $72 \mathrm{~h}$ to $12 \mathrm{~h}$ only so as the clearly demarcate the importance of PEG 6000 addition during enzymatic hydrolysis and its role in augmented glucose release from acid pretreated SCB.

\section{Determining the optimal duration of saccharification and protein loading for Cellic CTec2}

In a batch process involving lignocellulosic biomass hydrolysis, it is highly critical to determine enzyme dosing with maximum conversion yields within shorter incubation time, as it can play a significant role in reducing the overall cost economics of saccharification.

Therefore, to decipher the optimal dosage of Cellic CTec2 and the time duration after which there was a drastic reduction in hydrolysis rate of acid pretreated SCB, enzymatic saccharification was carried out at $7.5 \%$ substrate and different protein loadings of Cellic CTec2 namely 12.5, 25 and $37.5 \mathrm{mg}$ protein/g cellulose content. This experiment was carried out for $24 \mathrm{~h}$ with sample withdrawal after every 4 hours at optimum $\mathrm{pH}$, temperature and PEG 6000 concentrations conducive for Cellic CTec2.

Samples withdrawn after regular intervals were subjected to centrifugation $\left(7500 \mathrm{rpm}, 4^{\circ} \mathrm{C} ; 15 \mathrm{~min}\right)$. Glucose estimation and protein recovery studies were carried out in clarified saccharified broth.

\section{Glucose estimation by HPLC analysis and protein recovery}

After enzymatic saccharification, the glucose release in the saccharified broth was analyzed by highperformance liquid chromatography (HPLC) using an Aminex HPX-87H $300 \mathrm{~mm} \times 7.8 \mathrm{~mm}$ column with $9 \mu \mathrm{m}$ particle size (Bio-Rad, California, USA) equipped with auto-injector facility (SIL-20AC HT, Shimadzu Corporation Japan) and refractive index detector (RID-10A; Shimadzu Corporation Japan).

The analysis was done at $55{ }^{\circ} \mathrm{C}$ under isocratic conditions with $5 \mathrm{mM} \mathrm{H}_{2} \mathrm{SO}_{4}$ as the mobile phase at a flow rate of $0.55 \mathrm{~mL} / \mathrm{min}$ with an injection volume of $20 \mu \mathrm{L}$. A calibration curve was drawn using glucose as standards in the range of $0.2-1.0 \mathrm{mg} / \mathrm{ml}$.

Saccharification Efficiency (\%) was calculated using the following formula:

Saccharification Efficiency $(\%)=\quad($ Total glucose released in $\mathrm{g}) * 100$

$$
\text { Glucan content in the substrate }(\mathrm{g}) * 1.11
$$

Where 1.11 is the polymerization factor for cellulose 
The amount of protein recovered after saccharification was estimated by Bradford assay. Percentage recovery was calculated by the following formula:

Recovered enzyme in terms of protein $(\%)=($ Total Protein retained in saccharified broth $) * 100$

Initial Protein dosed

Where in protein content was reported as mg protein BSA equivalents

\section{First Round of Saccharification with Cellic CTec2}

After deciphering the optimal duration of saccharification and protein loading, the first round of saccharification was designed. This batch study was carried out with $22.5 \mathrm{~g}$ (on dry weight basis) acid pretreated SCB, with PEG 6000 added at a concentration of $0.2 \mathrm{~g} / \mathrm{g}$ AISL content. The reaction was initiated by adding of Cellic CTec2 (dosage of $25 \mathrm{mg}$ protein $/ \mathrm{g}$ cellulose content) followed by incubation at $50^{\circ} \mathrm{C}$. After $16 \mathrm{~h}$ of incubation, the reaction was terminated followed by centrifugation at $7500 \mathrm{rpm}$ for $45 \mathrm{~min}$ at $4^{\circ} \mathrm{C}$. Saccharification efficiency and protein recoveries were calculated in the clarified saccharified broth by estimation of glucose and protein respectively, as per the method described in subsection 2.4 .

The residual biomass obtained after the first round of saccharification was subjected to drying, followed by compositional analysis by NREL method (mentioned in subsection 2.2) for complete mass balance and validation of saccharification yield in the first round.

\section{Recycling of Cellic CTec2}

To evaluate the hydrolytic potential of recovered protein, the saccharified broth obtained after the first round of saccharification was concentrated. To achieve 5 fold concentration of saccharified broth, 50kDa PES centrifugal filters (Corning Spin-X UF 20) were used. The centrifugal filters were subjected to centrifugation at $2377 \mathrm{~g}$ equivalent to $4500 \mathrm{rpm}$ for $30 \mathrm{~min}$ at $4^{\circ} \mathrm{C}$. The concentrated saccharified broth was referred to as Retentate 1 (R1), and the glucose-rich broth devoid of protein was referred to as Permeate 1 (P1). Glucose and protein estimations were carried out both in R1 and P1 for assessing sugar and protein losses respectively.

\section{Second round of saccharification with recycled Cellic CTec2}

The retentate obtained after the first round of saccharification (R1) was subjected to a second round of saccharification using two different approaches. In the first approach, depending on the protein concentration substrate loading was done with no extra top-up of fresh protein. However, in the second approach $25 \%$ fresh protein was added. This experiment was done to adjudge the performance of recycled Cellic CTec2, with and without fresh protein top-up (Fig.1). 
All the saccharification conditions were identical as described in section 2.3. Glucose and protein estimation in the saccharified broths as mentioned in section 2.4 .

Second round of recycling was carried out as per the procedure used in the preceding section. After ultra filtration through 50kDa membrane, the two glucose-rich broths devoid of protein were referred as Permeate 2 without top (P2a) and Permeate 2 with top-up (P2b).

\section{Ethanol fermentation studies with glucose-rich saccharified broth obtained after the first and second} round of saccharification

This study was carried out to affirm the efficacy of glucose-rich saccharified broth for direct usage towards fermentative production of ethanol. Saccharomyces cerevisiae MTCC 180, procured from Institute of Microbial Technology (IMTECH), Chandigarh, India was selected based on an earlier report by Trivedi et al [19]. Before fermentation studies, all the saccharified broths (P1, P2a and P2b) obtained after the first and second round of saccharification were diluted to a concentration of $20 \mathrm{~g} / \mathrm{L}$ glucose. This solution was fortified with $1 \%$ $\left(\mathrm{NH}_{4}\right)_{2} \mathrm{SO}_{4}, 0.015 \% \mathrm{KH}_{2} \mathrm{PO}_{4}, 0.015 \% \mathrm{Na}_{2} \mathrm{HPO}_{4}, 0.1 \%$ yeast extract and $60 \mathrm{ppm} \mathrm{MgSO} \mathrm{Mg}_{4} .7 \mathrm{H}_{2} \mathrm{O}(\mathrm{pH}-4.5)$ and sterilized at $121^{\circ} \mathrm{C}$ for $15 \mathrm{~min}$. The sterilized broths were inoculated with an overnight grown culture of $S$. cerevisiae MTCC 180 and incubated at $30 \pm 2^{\circ} \mathrm{C}$.

After $8 \mathrm{~h}$, ethanol analysis was performed by withdrawing the fermentation broth, centrifugation at $7500 \mathrm{rpm}$ at $4^{\circ} \mathrm{C}$ in a bench top centrifuge and analysis in HPLC set up as described in section 2.4. The standard curve of ethanol was drawn in the range of 0.2 to $1 \mathrm{mg} / \mathrm{ml}$. Fermentation Efficiency for ethanol production was calculated as:

Ethanol fermentation Efficiency $(\%)=\underline{\text { Total ethanol yield }(\mathrm{g})} * 100$

Theoretical maximum yield of ethanol $(\mathrm{g})$

\section{Results and Discussion}

\section{Determining optimal pH, temperature and dosage of PEG 6000 for Cellic CTec2}

When the saccharification experiments were carried out with acid pretreated SCB using Cellic CTtec2, this commercial preparation exhibited a broad $\mathrm{pH}$ range that peaked at around 4.5 and when temperature studies were conducted with 4.5 as optimum $\mathrm{pH}$, maximum saccharification was observed at $50^{\circ} \mathrm{C}$ as shown in Table 1 . Taking 4.5 and $50^{\circ} \mathrm{C}$ as optimum when different concentrations of PEG $6000(0.1-0.5 \mathrm{~g} / \mathrm{g}$ AISL content $)$ were checked for improved saccharification efficiency following results were obtained as depicted in Figure 1. 
As observed in Figure 1, an incubation period of $12 \mathrm{~h}$ resulted in $67 \%$ release of glucose from the cellulosic fraction of acid pretreated bagasse when the PEG 6000 was added at a concentration of $0.2 \mathrm{~g} / \mathrm{g}$ AISL content. Thereafter further increase in PEG concentration did not promote glucose release.

However addition of this surfactant significantly improved the saccharification efficiency from $28.8 \%$ to $67 \%$ which clearly highlighted the role of PEG 6000 towards enhanced cellulose hydrolysis. Shorter incubation time of $12 \mathrm{~h}$ showed more pronounced effect of PEG 6000 addition as in our earlier studies we have shown only $21 \%$ improvement (69\% to $83 \%)$ in saccharification efficiency by Cellic CTec 2 when acid pretreated sugarcane bagasse hydrolysis was carried out for $72 \mathrm{~h}$ with and without surfactant addition [9]. The present data is far superior to the results obtained by Alhammad et al., who reported 19.2\% improvement in enzymatic saccharification of 5\% steam pretreated poplar when PEG 4000 was added at a concentration of $1 \% \mathrm{w} / \mathrm{w}$ after 96h of hydrolysis with Cellic CTec2 added at a concentration of 5\% w/w basis [12].

Moreover, this experiment also highlighted that increasing the duration of hydrolysis from $12 \mathrm{~h}$ to $72 \mathrm{~h}$ resulted in release of $17 \%$ more glucose only. Therefore it became crucial to know that rate kinetics of Cellic CTec 2 by performing hydrolysis of acid pretreated SCB with varying protein loading of Cellic CTec2 and optimal duration of hydrolysis.

\section{Determining the optimal duration of saccharification and protein loading for Cellic CTec2}

When the saccharification experiments were carried out with acid pretreated bagasse at different protein loading of Cellic CTec2 across different time points following were the results as obtained in Fig 2a.

As observed in Figure 2a, increasing protein loading favoured higher saccharification of acid pretreated SCB.

However, loading Cellic CTec2 at higher protein concentration also led to early attainment of product saturation, as a result of rapid saccharification.

When the protein loading of Cellic CTec 2 was increased from 12.5 to $25 \mathrm{mg} / \mathrm{g}$ cellulose content, there was a prominent increase of $54 \%$ in the saccharification efficiency within $4 \mathrm{~h}$ of incubation time. However, a further increase to $37.5 \mathrm{mg} / \mathrm{g}$ cellulose content could marginally improve the glucose release from acid pretreated SCB by $4.9 \%$ within the first $4 \mathrm{~h}$. Thus among the three protein loadings, dosing Cellic CTec 2 at $25 \mathrm{mg}$ protein loading /g cellulose content basis seemed more appropriate for enzymatic saccharification. As the time duration increased from $4 \mathrm{~h}$ to $12 \mathrm{~h}$, the rate of hydrolysis at $25 \mathrm{mg}$ protein loading slowed down attaining saturation after $16 \mathrm{~h}(68.7 \%$ in $12 \mathrm{~h}$ to $71.1 \%$ in $24 \mathrm{~h})$. Similar observations were made by Qi et al. when they carried out hydrolysis of steam-exploded wheat straw by commercial cellulase, wherein saccharification efficiency increased from $81.3 \%$ to $84.5 \%$ only as time proceeded from 24 h to $48 \mathrm{~h}$ [20]. 
When the protein recovery studies were performed in the saccharified broth, irrespective of different protein loading, $60-70 \%$ protein remained adsorbed to the bagasse (Figure $2 \mathrm{~b}$ ). Shorter incubation time and availability of cellulose for hydrolysis possibly attributed to lower detection of free protein in the saccharified broth.

However, a significant positive correlation was observed between the rate of hydrolysis and protein desorption at protein loading of $12.5 \mathrm{mg} / \mathrm{g}$ cellulose content. At $25 \mathrm{mg} / \mathrm{g}$ cellulose content, best recoveries of Cellic CTec 2 was obtained after $16 \mathrm{~h}$ incubation as seen in Figure $2 \mathrm{~b}$. Hence Cellic CTec 2 loading at $25 \mathrm{mg} / \mathrm{g}$ cellulose content for $16 \mathrm{~h}$ incubation time was chosen for the first round of saccharification.

\section{First round of saccharification with acid pretreated SCB using Cellic CTec2}

When the bulk hydrolysis of $22.5 \mathrm{~g}$ acid pretreated SCB was carried out for $16 \mathrm{~h}$ in duplicates, following was the saccharification and protein recovery efficiency as shown in Table $2 \mathrm{a}$.

PEG 6000 mediated hydrolysis of acid pretreated sugarcane bagasse resulted in $76.24 \%$ glucan hydrolysis using Cellic CTec2 within a short span of 16h (Table 2a). Earlier a number of workers have used Cellic CTec2 for hydrolysis of various lignocellulosic feedstocks and have obtained varying results as depicted in Table $2 \mathrm{~b}$. However, in the present study use of PEG 6000 at a concentration of $0.2 \mathrm{~g} / \mathrm{g}$ AISL content not only reduced the duration of cellulose hydrolysis significantly but also facilitated desorption of more than 55\% protein of Cellic CTec2 from lignin-rich biomass. Earlier Rodrigues et al have reported 58\%, 35\% and 74\% recovery of cellobiohydrolase (CBHI), endoglucanase (EG I) and $\beta$-glucosidase respectively for Cellic CTec2 enzyme using alkaline washing [25]. Gomes et al. have also reported an overall recovery of $60.2 \%$ for Cellic CTec 2 after enzymatic hydrolysis followed by alkaline elution [26].

When the mass balance studies were carried out with the residual biomass, obtained after 16h of enzymatic saccharification, the acid insoluble content increased from $33 \%$ to $56 \%$ and hydrolysis of cellulose decreased its content from $55 \%$ to merely $24 \%$ as shown in Table 3 . The material balance studies using residual biomass reaffirmed that the saccharification of acid pretreated SCB was $\sim 74 \%$ in the first round.

\section{Recycling of Cellic CTec2 after the first round of saccharification}

When the enzyme recycling was carried out using $50 \mathrm{kDa}$ PES centrifugal filters, the following was the distribution pattern of glucose and protein in the retentate (R1) and permeate (P1), as shown in Table 4. Membrane filtration served a dual purpose in the present study. The obtained retentate contained protein in concentrated (4.5 times) form with an effective recovery of $89 \%$ whereas permeate retained almost $69.2 \%$ glucose with virtually no enzyme protein (Table 4). 
Thus permeate (P1) could serve as a sole source of glucose for direct ethanol fermentation. These results are in consensus with the results of Qi et al, where they could recover 87.5\% enzyme protein using 30kDa PES membrane with a permeate flux of $53.11 / \mathrm{m}^{2} \mathrm{~h}$, but simultaneously could retrieve only $41.4 \%$ glucose [20]. However, Kuntsen and Davis have provided contradictory evidence with cellulases from Iogen Corporation where 50kDa PES membranes were found to be effective to retain active enzyme [27].

\section{Second round of saccharification with acid pretreated SCB using recycled Cellic CTec2}

The second round of saccharification studies was carried out with recycled Cellic CTec2 (R1) with two different approaches (without protein top-up and with $25 \%$ protein top-up). In spite of losing a significant fraction of protein $(\sim 41.5 \%)$ in the first round of saccharification, the recycled Cellic CTec2 without protein up could depolymerise cellulose of acid pretreated SCB with only $12 \%$ reduced glucose release as shown in Figure 3. This result indicated that in the first round of saccharification, most of the protein lost in the bagasse belonged to the non-cellulase fraction (Fig 3). However, an entirely different conclusion could be drawn considering the combined results of the first round and second round of saccharification. The combined results strongly suggested that only $40-45 \%$ protein of Cellic CTec 2 remained adsorbed to the acid pretreated bagasse and was instrumental in catalyzing the hydrolysis of the cellulosic fraction.

These results are in concurrence with the studies of $\mathrm{Hu}$ et al, who concluded that enzymatic hydrolysis is principally governed by the indispensable role of the initial adsorbed enzyme to the biomass [28].

Therefore, further topping up of $25 \%$ protein during the second round of saccharification led to a meager increase of $8.4 \%$ in saccharification, but at the same time, $25 \%$ more protein losses were as observed as shown in Figure 3.

When the material balance studies were carried out with the residual biomasses obtained after the second round of saccharification, the following results were obtained as shown in Table 5. Residual biomass analysis confirmed that hydrolysis during the second of saccharification was $\sim 71 \%$ regardless of fresh top-up. These studies confirmed that by recycling Cellic CTec2 enzyme using a combination of PEG 6000 and membrane filtration $(50 \mathrm{kDa})$, the effective protein loading could be reduced from $25 \mathrm{mg}$ protein $/ \mathrm{g}$ cellulose to $16.8 \mathrm{mg}$ protein/g cellulose with average saccharification of $\sim 72 \%$ within $16 \mathrm{~h}$, in a two-stage batch mode. These results are highly encouraging in the light of the previous study done by Haven et al, who reported 5\% reduction in enzyme loading after recycling of Cellic CTec2 during hydrolysis of acid pretreated wheat straw [29]. 


\section{Recycling of Cellic CTec2 after the second round of saccharification}

When the second round of recycling was carried out for Cellic CTec2 using $50 \mathrm{kDa}$ PES membrane, the following was the distribution of glucose in retentate (R2a and R2b) and permeates (P2a and P2b) as shown in Table 6. The results indicated that in the second round of recycling, the glucose recoveries were better (more than $93 \%$ ) in the two permeates (P2a and $\mathrm{P} 2 \mathrm{~b}$ ) as compared to $\sim 70 \%$ glucose in permeate (P1) obtained in the first round of saccharification. The glucose-rich permeates were thus the direct source of carbon for ethanol fermentation studies.

The better glucose recoveries during second round of recycling may be a culmination of lower volumes of saccharified broth and use of fresh 50kDa PES membranes. Earlier in the first round of recycling due to higher volumes of saccharified broth $(\sim 300 \mathrm{ml})$ and repeated use of membrane there was higher probability of thin film formation of membrane resulting in lower glucose recovery.

\section{Ethanol fermentation studies with the glucose-rich saccharified broth obtained after the first and second round of saccharification}

When the ethanol fermentation studies were carried out with the $50 \mathrm{kDa}$ permeates obtained after the first and second round of saccharification using Saccharomyces cerevisiae MTCC 180, the following results were obtained as depicted in Figure 4. Irrespective of the type of permeates; the ethanol fermentation efficiency of the said yeast was more than $82 \%$. Similar kind of result had been reported with Saccharomyces cerevisiae NCIM 3521 when glucose and xylose-rich broth was used after enzymatic saccharification of ammonia-treated sugarcane bagasse [30].

Thus the present study concluded with the fact that surfactant aided enzymatic hydrolysis of acid pretreated bagasse within a short span of $16 \mathrm{~h}$ was successfully able to desorb more than $55 \%$ protein of Cellic CTec 2 in the glucose-rich liquid fraction. Further use of 50KDa PES membrane not only effectively concentrated this desorbed protein but could fractionate $80 \%$ glucose in its permeate. When this recycled concentrated Cellic CTec2 was used for subsequent hydrolysis, more than $70 \%$ glucose yields were obtained, a result comparable to the first round of saccharification (76.24\%). Fortification with fresh protein top-up of $25 \%$ could not significantly enhance the sugar release as compared to unfortified saccharification reaffirming the studies of $\mathrm{Hu}$ et al which suggested that enzymatic saccharification is primarily driven by initially adsorbed enzyme only [28]. 
The study further affirmed that the fractionated glucose-rich permeates obtained after the first and second round of saccharification could serve as direct carbon sources for ethanol fermentation.

The summary of the entire experimental work has been presented in Figure 5 wherein data has been extrapolated to $100 \mathrm{~g}$ of initial acid pretreated sugarcane bagasse and ethanol yields have been highlighted with one step recycling of Cellic CTec2.

In the future, we aim to replicate our results with Cellic CTec2 at high solid loading (15-20\%) which would help us in achieving saccharified broth with high glucose concentrations. Simultaneously we also target for large scale saccharification trials, where multiple rounds of recycling and subsequent hydrolyses can be attempted. Thus we seek to get a better insight on repeated use of this commercial enzyme preparation at the industrial level.

\section{Conclusion}

This study illustrated that high enzyme loading is fundamentally not a pre-requisite for attaining a higher rate of cellulose hydrolysis. Use of simple additives such as PEG 6000 can significantly reduce the duration of saccharification without compromising on glucose yields. Moreover, its use can also reduce the unwanted and irreversible protein loss, whose potentiality can be harnessed in subsequent hydrolysis by applying an appropriate strategy.

\section{Acknowledgement}

This work is financially supported by the Department of Biotechnology (DBT, India) under Indo-UK Industrial Waste Challenge 2017, with grant number being GAP 3513. The authors are thankful to Dr Anjan Ray, Director CSIR-Indian Institute of Petroleum for providing necessary facilities to complete this work and his constant motivation. Mrs. Lavika Jain is grateful to Council of Scientific and Industrial Research (CSIR) New Delhi, India for awarding her Senior Research Fellowship.

\section{Compliance with ethical standards}

\section{Conflict of interest}

The authors declare that they have no conflict of interest.

\section{References:}

1. Carriquiry MA, Du X, Timilsina GA (2011) Second generation biofuels: Economics and policies. Energy Policy 39: 4222-4234.

2. Lynd LR, Liang X, Biddy MX, Allee A, Cai H, Foust T, Himmel ME, Laser MS, Wang M, Wyman CE (2017) Cellulosic ethanol: status and innovation. Curr Opin Biotechnol 45: 202-211. 
3. Mohanram S, Amat D, Choudhary J, Arora A, Nain L (2013) Novel perspectives for evolving enzyme cocktails for lignocellulose hydrolysis in biorefineries. Sustain Chem Process 1:15.

4. Nguyen TY, Caib CM, Kumar R, Wyman CE (2017) Overcoming factors limiting high-solids fermentation of lignocellulosic biomass to ethanol. PNAS. 114: 11673-11678.

5. Berlin A, Gilkes N, Kurabi A, Bura R, Tu M, Kilburn D, Saddler J (2005) Weak Lignin-Binding Enzymes, A novel approach to improve activity of cellulases for hydrolysis of lignocellulosics. Appl Biochem Biotechnol 121: 163-170.

6. Whitehead TA, Bandi CK, Berger M, Park J, Chundawat SPS (2017) Negatively Supercharging Cellulases Render Them Lignin-Resistant. ACS Sustain Chem Engg. 5: 6247-6252.

7. Gomes DG, Serna-Loaiza,S, Cardona CA, Gama M, Domingues L (2018) Insights into the economic viability of cellulases recycling on bioethanol production from recycled paper sludge. Bioresour Technol 267: $347-355$.

8. Rodrigues AC, Felby C, Gama M (2014) Cellulase stability, adsorption/desorption profiles and recycling during successive cycles of hydrolysis and fermentation of wheat straw. Bioresour Technol 156: 163-169.

9. Jain L, Kurmi AK, Agrawal D (2018) Feasibility studies with lignin blocking additives in enhancing saccharification and cellulase recovery: Mutant UV-8 of T. verruculosus IIPC 324 a case study. Enzyme Microb Technol 118: 44-49.

10. Fahmy M, Sohel MI, Vaidya AA, Jack MW, Suckling ID (2019) Does sugar yield drive lignocellulosic sugar cost? Case study for enzymatic hydrolysis of softwoods with added polyethylene glycol. Proc Biochem 80:103-111

11. Luo X, Liu J, Zheng P, Li M, Zhou Y, Huang L, Chen L, Shuai L (2019) Promoting enzymatic hydrolysis of lignocellulosic biomass by inexpensive soy protein. Biotechnol Biofuels. 12:51.

12. Alhammad A, Adewale P, Kuttiraja M, Christopher LP (2018) Enhancing enzyme-aided production of fermentable sugars from poplar pulp in the presence of non-ionic surfactants. Biprocess Biosys Eng 41(8):1133-1142.

13. Olson DG, McBride JE, Shaw AJ, Lynd LR (2011) Recent progress in consolidated bioprocessing. Curr Opin Biotechnol 23:1-10.

14. Gomes D, Rodrigues AC, Domingues L, Gama M (2015) Cellulase Recycling in biorefineries- is it possible? Appl Microbiol Biotechnol 99: 4131-4143. 
15. Jørgensen H, Pinelo M (2016) Enzyme recycling in lignocellulosic biorefineries. Biofuel Bioprod Biorefin 11: 150-167.

16. Bradford MM (1976) A Rapid and Sensitive Method for the Quantitation of Microgram Quantities of Protein Utilizing the Principle of Protein-Dye Binding. Anal Biochem 72: 248-254.

17. Ghosh D, Dasgupta D, Agrawal D, Kaul S, Adhikari DK, Kurmi AK, Arya PK, Bangwal D, Negi MS (2015) Fuels and chemicals from lignocellulosic biomass: An integrated biorefinery approach. Energ Fuel 29: $3149-3157$.

18. Sluiter A, Hames B, Ruiz R, Scarlata C, Sluiter J, Templeton D, Crocker D (2012) Determination of structural carbohydrates and lignin in biomass. D. NREL/TP-510-42618.

19. Trivedi N, Baghel RS, Bothwell J, Gupta V, Reddy RK, Lali AM, Jha B (2016) An integrated process for the extraction of fuel and chemicals from marine macroalgal biomass. Sci Rep 6: 30728 .

20. Qi B, Luo J, Chen G, Chen X, Wan Y (2012) Application of ultrafiltration and nanofiltration for recycling cellulase and concentrating glucose from enzymatic hydrolyzate of steam exploded wheat straw. Bioresour Technol 104: 466-472

21. Reis L, Fontana RC, Delabona PS, Lima DJS, Camassola M,. Pradella JGC, Dillon AJP (2013) Increased production of cellulases and xylanases by Penicillium echinulatum S1M29 in batch and fed-batch culture. Bioresour Technol 146: 597-603.

22. Sun FF, Hong J, Hu J, Saddler JN, Fang X, Zhang Z, Shen S (2015) Accessory enzymes influence cellulase hydrolysis of the model substrate and the realistic lignocellulosic biomass, Enzyme Microb Technol 79-80: 42-48.

23. Ramos LP, Silva L, Ballem AC, Pitarelo AP, Chiarello LM, Silveira MHL (2015) Enzymatic hydrolysis of steam-exploded sugarcane bagasse using high total solids and low enzyme loadings. Bioresour Technol 175: $195-202$.

24. Cannella D, Hsieh CC, Felby C, Jørgensen H (2012) Production and effect of aldonic acids during enzymatic hydrolysis of lignocellulose at high dry matter content, Biotechnol Biofuels. 5:26.

25. Rodrigues AC, Haven MØ, Lindedam J, Felby C, Gama M (2015) Celluclast and Cellic $®$ CTec2: Saccharification/fermentation of wheat straw, solid-liquid partition and potential of enzyme recycling by alkaline washing, Enzyme Microb Technol 79-80: 70-77. 
26. Gomes D, Gama M, Domingues L (2018) Determinants on an efficient cellulase recycling process for the production of bioethanol from recycled paper sludge under high solid loadings, Biotechnol Biofuels 11:111.

27. Knutsen JS, Davis RH (2004) Cellulase retention and sugar removal by membrane ultrafiltration during lignocellulosic biomass hydrolysis. Appl Biochem Biotechnol. 114: 585-600.

28. Hu J, Mok YK, Saddler JN (2018) Can we reduce the cellulase enzyme loading required to achieve efficient lignocellulose deconstruction by only using the initially absorbed enzymes? ACS Sustain Chem Engg. 6: 6233-6239.

29. Haven MØ, Lindedam J, Jeppesen MD, Elleskov M, Rodrigues AC, Gama M, Jørgensen H, Felby C (2015) Continuous recycling of enzymes during production of lignocellulosic bioethanol in demonstration scale, Appl Energ. 159: 188-195.

30. Patel H, Chapla D, Shah A (2017) Bioconversion of pretreated sugarcane bagasse using enzymatic and acid followed by enzymatic hydrolysis approaches for bioethanol production, Renew Energ. 109: 323-331. 


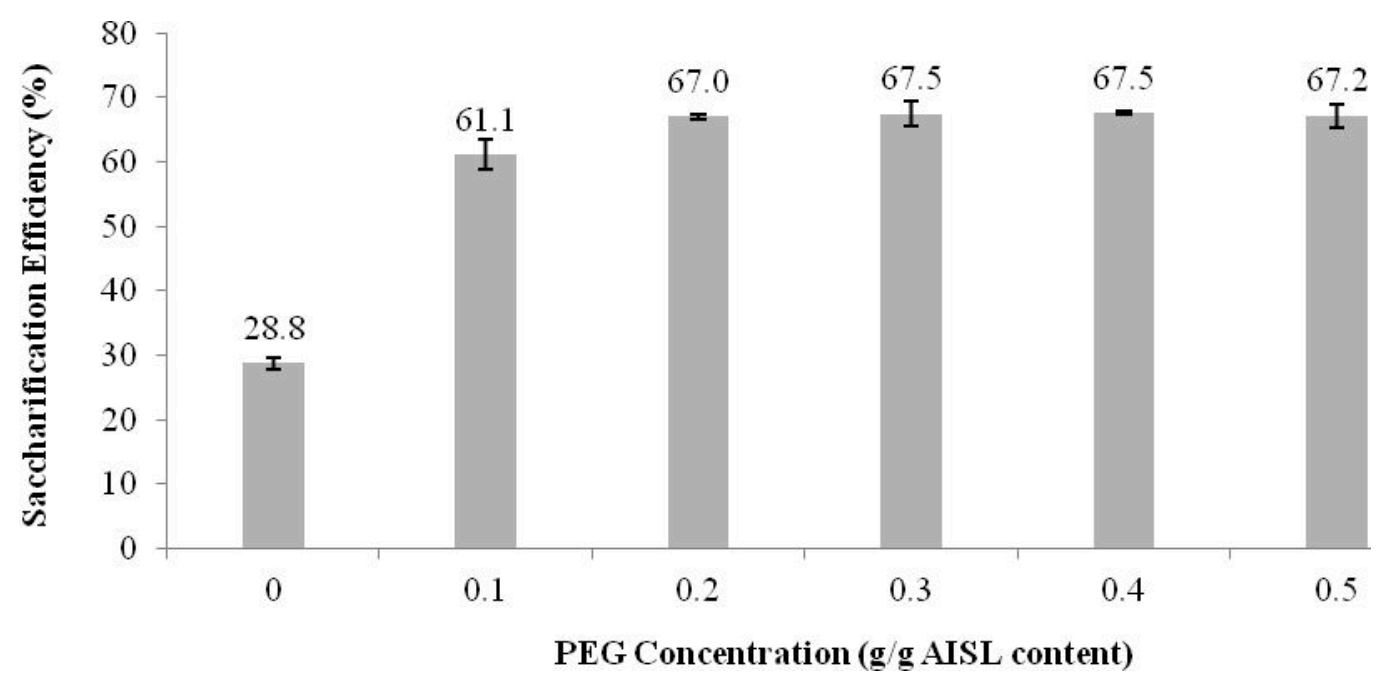

Figure 1 


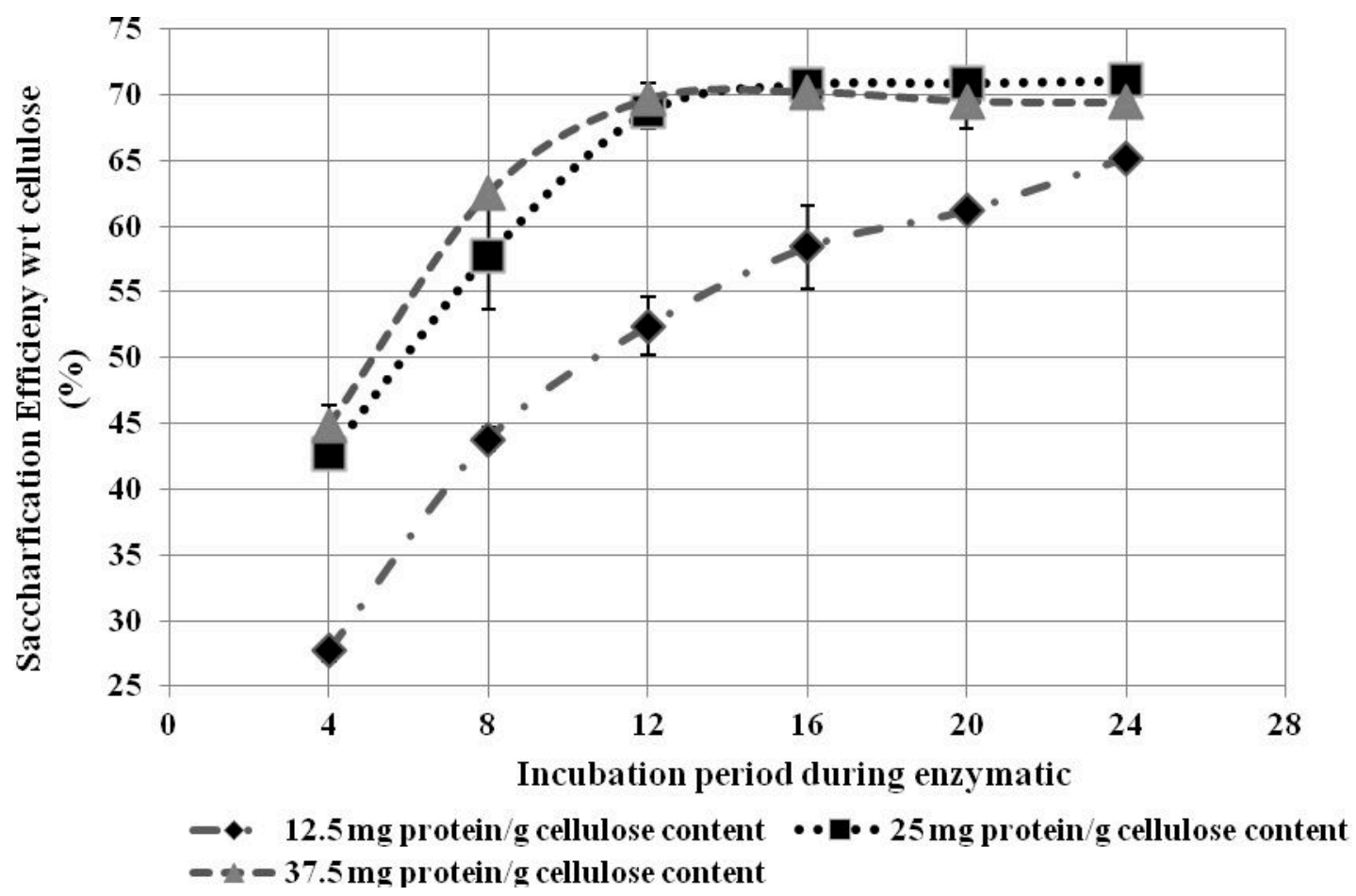

Figure 2a 


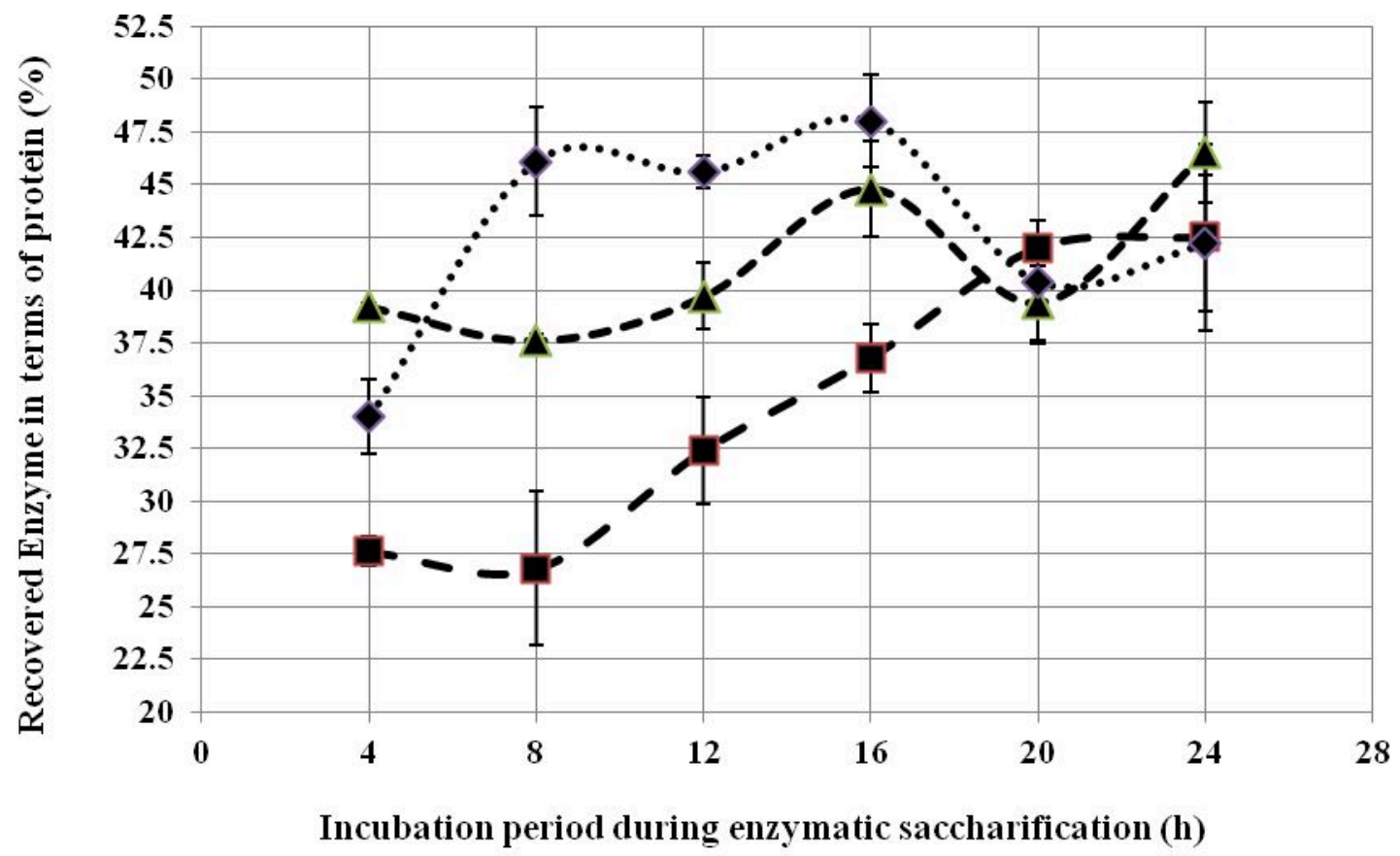

$-\square-12.5 \mathrm{mg}$ protein $/ \mathrm{g}$ cellulose content $\quad-2-25 \mathrm{mg}$ protein $/ \mathrm{g}$ cellulose content $\cdots \bullet \cdot 37.5 \mathrm{mg}$ protein $/ \mathrm{g}$ cellulose content

Figure 2b 


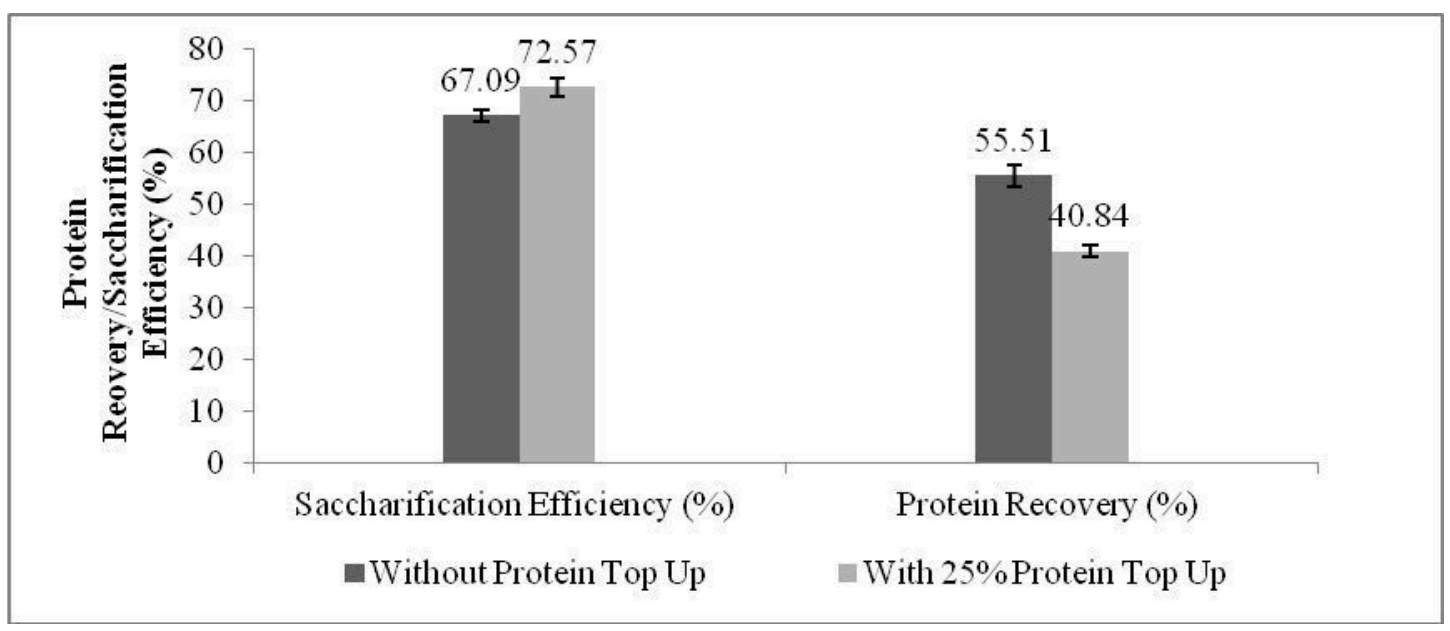

Figure 3 


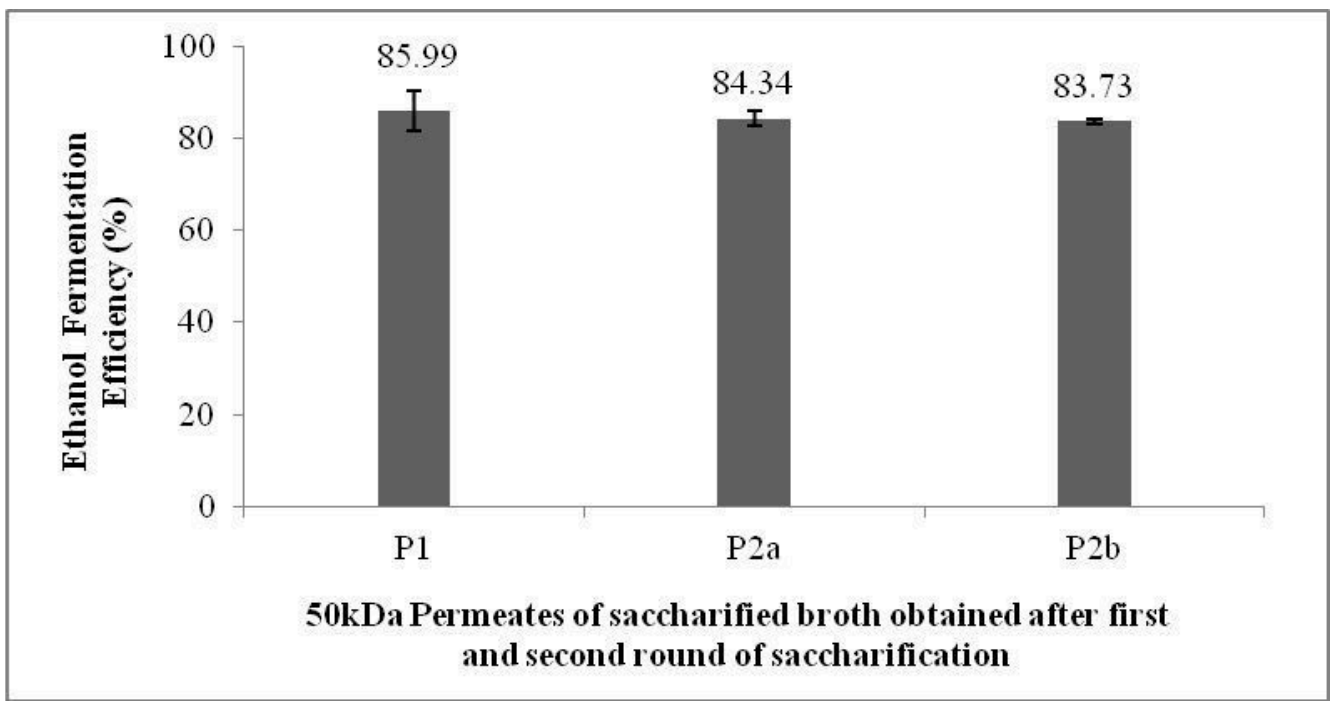

Figure 4 
Acid Pretreated Sugarcane

Bagasse (100 g)

$\square$ Cellulose : $55.14 \mathrm{~g}$

Acid Insoluble Lignin: $33.73 \mathrm{~g}$

$\square$ Xylan : $2.92 \mathrm{~g}$

Saccharification of $25.94 \mathrm{~g}$ acid pretreated sugarcane bagasse

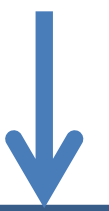

Saccharified broth containing:

Glucose : $10.65 \mathrm{~g}$

Enzyme protein : $0.198 \mathrm{~g}$

Retentate with 0.137 g protein
Permeate with 10.02 g glucose

Ethanol: $4.30 \mathrm{~g}$
Cellic C Tec2: $1.378 \mathrm{~g}$ protein
Saccharified broth containing:

Glucose : $46.67 \mathrm{~g}$

Recovered protein : $\mathbf{0 . 8 0 7} \mathrm{g}$

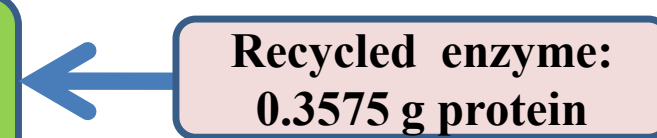

0.3575 g protein
Retentate with

0.715 g protein
Permeate with 37.43 g glucose

Recycled enzyme with $\mathbf{2 5 \%}$ fresh protein top up

19

Saccharification of $\mathbf{3 4 . 5 7} \mathrm{g}$ acid pretreated sugarcane bagasse

Saccharified broth containing: Glucose : $15.36 \mathrm{~g}$

Enzyme protein : $0.194 \mathrm{~g}$

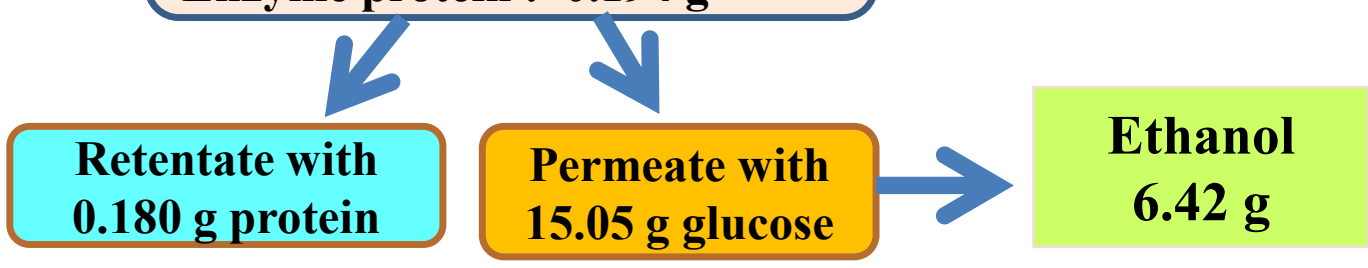

Ethanol yield ( $27.3 \mathrm{~g}$ ) from $160 \mathrm{~g}$ acid pretreated bagasse by one stage recycling of Cellic CTec2 in 16h saccharification process 


\section{Figure Captions}

Fig 1 Effect of increasing concentration of PEG 6000 (g/g AISL content) on enzymatic saccharification of acid pretreated bagasse by Cellic CTtec2 after $12 \mathrm{~h}$ of incubation at $\mathrm{pH} 4.5$ and $50^{\circ} \mathrm{C}$

Fig 2a Time course of enzymatic saccharification during hydrolysis of acid pretreated sugarcane bagasse at the different dosage of Cellic CTec2 with a temperature being $50^{\circ} \mathrm{C}$ and $\mathrm{pH} 4.5$

Fig2b Protein recoveries (\%) after enzymatic saccharification of acid pretreated sugarcane bagasse at the different dosage of Cellic CTec2 on various time intervals

Fig 3 Saccharification efficiency $(\%)$ and protein recovery $(\%)$ with recycled unfortified and fortified (25\% fresh protein top-up) Cellic CTec2

Fig 4 Ethanol fermentation efficiency of various glucose-rich permeates obtained first and second round of saccharification with Cellic CTec2 after $8 \mathrm{~h}$ incubation with Saccharomyces cerevisiae MTCC 180

Fig 5 Ethanol yield from initial biomass of $100 \mathrm{~g}$ (acid pretreated SCB) by one stage recycling of Cellic CTec2 in 16h saccharification process 
Table 1- Effect of pH and temperature during enzymatic saccharification of acid pretreated sugarcane bagasse with Cellic CTec2

\begin{tabular}{cccc}
\hline $\mathbf{p H}$ & $\begin{array}{c}\text { Saccharification Efficiency (\%) w.r.t } \\
\text { glucose released after } \mathbf{7 2 h} \text { at } \mathbf{5 0} \mathbf{}^{\circ} \mathbf{C}\end{array}$ & $\begin{array}{c}\text { Temperature } \\
\left({ }^{\circ} \mathbf{C}\right)\end{array}$ & $\begin{array}{c}\text { Saccharification Efficiency (\%) w.r.t } \\
\text { glucose released after 72h at } \mathbf{~ p H ~ 4 . 5}\end{array}$ \\
\hline 4 & $80.92 \pm 1.05$ & 45 & $75.17 \pm 1.76$ \\
4.5 & $84.07 \pm 2.36$ & 50 & $84.07 \pm 2.36$ \\
5.0 & $81.47 \pm 2.36$ & 55 & $78.73 \pm 0.71$ \\
5.5 & $78.04 \pm 4.89$ & 60 & $79.64 \pm 2.92$ \\
6.0 & $73.76 \pm 0.66$ & - & - \\
\hline
\end{tabular}

Note: The values are the average of duplicates \pm standard deviation 
Table 2a: Performance of Cellic CTec2 after $16 \mathrm{~h}$ hydrolysis of acid pretreated sugarcane bagasse in terms of saccharification efficiency and protein recovery.

\begin{tabular}{cc}
\hline Cellic CTec2 & $\begin{array}{c}\text { After 16 h of enzymatic hydrolysis of } \\
\text { Acid pretreated SCB }\end{array}$ \\
\hline (25mg protein/g cellulose content) & $76.24 \pm 2.18$ \\
Paccharification Efficiency (\%) & $58.4 \pm 1.09$ \\
\hline
\end{tabular}


Table 2b: Saccharification Efficiency of Cellic CTe2 on various lignocellulosic biomasses pretreated with different methods as cited in state of art.

\begin{tabular}{|c|c|c|c|c|}
\hline $\begin{array}{l}\text { Biomass } \\
\text { Type }\end{array}$ & $\begin{array}{l}\text { Pretreatment } \\
\text { method }\end{array}$ & $\begin{array}{c}\text { Conditions during enzymatic } \\
\text { saccharification }\end{array}$ & $\begin{array}{c}\text { Saccharification } \\
\text { Efficiency (\%) } \\
\text { w.r.t. glucose } \\
\end{array}$ & Reference \\
\hline $\begin{array}{l}\text { Sugarcane } \\
\text { Bagasse }\end{array}$ & $\begin{array}{l}\text { Steam } \\
\text { Explosion }\end{array}$ & $\begin{array}{l}\text { Temp- } 50^{\circ} \mathrm{C}, \mathrm{pH}-4.8 \\
\text { Substrate loading- } 5 \% \\
\text { Enzyme loading- } 12.84 \mathrm{FPU} / \mathrm{g} \text { cellulose } \\
\text { Incubation time: } 72 \mathrm{~h}\end{array}$ & $28 \%$ & {$[21]$} \\
\hline $\begin{array}{l}\text { Sweet } \\
\text { Sorghum } \\
\text { Bagasse }\end{array}$ & $\begin{array}{c}\text { Steam } \\
\text { Pretreatment }\end{array}$ & $\begin{array}{l}\text { Temp- } 50^{\circ} \mathrm{C}, \mathrm{pH}-4.8 \\
\text { Substrate loading- } 2 \% \\
\text { Enzyme loading- } 36 \mathrm{mg} \text { protein } / \mathrm{g} \\
\text { cellulose } \\
\text { Incubation time: } 24 \mathrm{~h}\end{array}$ & $55 \%$ & {$[22]$} \\
\hline $\begin{array}{l}\text { Sugarcane } \\
\text { Bagasse }\end{array}$ & $\begin{array}{c}\text { Impregnation } \\
\text { of dilute } \\
\mathrm{H}_{3} \mathrm{PO}_{4} \\
\text { followed by } \\
\text { steam } \\
\text { Explosion } \\
\end{array}$ & $\begin{array}{l}\text { Temp- } 50^{\circ} \mathrm{C}, \mathrm{pH}-4.8 \\
\text { Substrate loading-5\% } \\
\text { Enzyme loading- } 33 \mathrm{FPU} / \mathrm{g} \text { cellulose } \\
\text { Incubation time: } 24 \mathrm{~h}\end{array}$ & $66.8 \%$ & {$[23]$} \\
\hline $\begin{array}{l}\text { Wheat } \\
\text { Straw }\end{array}$ & Hydrothermal & $\begin{array}{l}\text { Temp- } 50^{\circ} \mathrm{C}, \mathrm{pH}-5.0 \\
\text { Substrate loading- } 30 \% \\
\text { Enzyme loading- } 18.62 \mathrm{mg} / \mathrm{g} \text { cellulose } \\
\text { Incubation time: } 144 \mathrm{~h}\end{array}$ & $85 \%$ & {$[24]$} \\
\hline $\begin{array}{l}\text { Sugarcane } \\
\text { Bagasse }\end{array}$ & $\begin{array}{c}\text { Dilute acid } \\
\text { pretreatment }\end{array}$ & $\begin{array}{l}\text { Temp- } 50^{\circ} \mathrm{C}, \mathrm{pH}-4.5 \\
\text { Substrate loading- } 7.5 \% \\
\text { Enzyme loading- } 25 \mathrm{mg} \text { protein } / \mathrm{g} \\
\text { cellulose } \\
\text { Incubation time: } 16 \mathrm{~h}\end{array}$ & $\sim 75 \%$ & This study \\
\hline
\end{tabular}


Table 3: Compositional analysis of the residual acid pretreated sugarcane bagasse after enzymatic saccharification with Cellic CTec2 at loading of $25 \mathrm{mg}$ protein/g cellulose content and percentage cellulose hydrolysis as reflected by residual biomass composition

\begin{tabular}{cccccc}
\hline Biomass & $\begin{array}{c}\text { Weight in } \\
\text { g }\end{array}$ & \% AISL & \% Cellulose & \% Xylan & $\begin{array}{c}\text { Saccharification Efficiency } \\
\text { as per residual biomass } \\
\text { analysis }\end{array}$ \\
\hline Initial & 22.5 & $33.73 \pm 0.21$ & $55.14 \pm 1.21$ & $2.92 \pm 1.21$ & $73.80 \%$ \\
Residual & 13.4 & $56.3 \pm 0.49$ & $24.25 \pm 0.48$ & $1.88 \pm 0.05$ & \\
\hline
\end{tabular}


Table 4: Distribution pattern of protein and glucose after 50KDa PES membrane filtration of Cellic CTec2 containing saccharified broth of acid pretreated sugarcane bagasse

\begin{tabular}{lccc}
\hline \multicolumn{1}{c}{ Samples } & Volume $(\mathbf{m l )}$ & $\begin{array}{c}\text { Total Protein } \\
\text { (mg BSA equivalents) }\end{array}$ & $\begin{array}{c}\text { Protein Recovered } \\
(\%)\end{array}$ \\
\hline Initial Enzyme loading & & 310.16 & $-\mathrm{NA}-$ \\
Saccharified Broth** & 300 & 173 & 58.39 \\
50kDa Retentate I (R1) & 61 & 154.33 & 89.2 \\
50 kDa Permeate I (P1) & 232 & 18.0 & 10.4 \\
\hline \multicolumn{1}{c}{ Samples } & Volume (ml) & Total Glucose (g) & Glucose Distribution \\
& & & $\mathbf{( \% )}$ \\
\hline Saccharified Broth** & 300 & 10.43 & 19.8 \\
50kDa Retentate I (R1) & 61 & 2.066 & 69.22 \\
50 kDa Permeate I (P1) & 232 & 7.22 &
\end{tabular}

Note: **The total volume of saccharified broth was $302 \mathrm{ml}$ of which $300 \mathrm{ml}$ was subjected to membrane filtration 
Table 5: Compositional analysis of the residual acid pretreated sugarcane bagasse after enzymatic saccharification with recycled Cellic CTec2 at loading of $25 \mathrm{mg}$ protein/g cellulose content and percentage cellulose hydrolysis as reflected by residual biomass composition

\begin{tabular}{cccccc}
\hline Biomass & $\begin{array}{c}\text { Weight } \\
\text { in } \mathbf{~ g ~}\end{array}$ & \% AISL & \% Cellulose & \% Xylan & $\begin{array}{c}\text { Saccharification } \\
\text { efficiency }\end{array}$ \\
\hline $\begin{array}{c}\text { Initial biomass without } \\
\text { protein top up }\end{array}$ & 5.5 & $33.73 \pm 0.21$ & $55.14 \pm 1.21$ & $2.92 \pm 1.21$ & \\
$\begin{array}{c}\text { Residual biomass without } \\
\text { protein top up }\end{array}$ & 3.4 & $53.8 \pm 0.63$ & $26.44 \pm 1.46$ & $1.81 \pm 0.26$ & $70.35 \%$ \\
$\begin{array}{c}\text { Initial biomass with 25\% } \\
\text { protein top up }\end{array}$ & 7.5 & $33.73 \pm 0.21$ & $55.14 \pm 1.21$ & $2.92 \pm 1.21$ & $72.28 \%$ \\
$\begin{array}{c}\text { Residual biomass with } \\
\text { 25\% protein top up }\end{array}$ & 4.4 & $56.8 \pm 1.13$ & $26.04 \pm 0.86$ & $2.05 \pm 0.08$ & \\
\hline
\end{tabular}


Table 6: Glucose Distribution of saccharified broth containing recycled Cellic CTec2 (with and without $\mathbf{2 5 \%}$ fresh protein top up) after 50KDa PES membrane filtration

\begin{tabular}{lcccc}
\hline \multicolumn{1}{c}{ Samples } & Details & $\begin{array}{c}\text { Volume } \\
(\mathbf{m l})\end{array}$ & $\begin{array}{c}\text { Total Glucose } \\
(\mathbf{g})\end{array}$ & $\begin{array}{c}\text { Glucose Distribution } \\
\mathbf{( \% )}\end{array}$ \\
\hline Saccharified Broth IIa & Recycled & 85 & 3.27 & \\
50kDa Retentate IIa (R2a) & Cellic CTec2 & 4.5 & 0.15 & 4.58 \\
50 kDa Permeate IIa (P2a) & & 80 & 3.08 & 94.18 \\
\hline Saccharified Broth IIb & Recycled & 100 & 4.35 & \\
50kDa Retentate IIb (R2b) & Cellic CTec2 & 1.8 & 0.05 & 1.15 \\
50 kDa Permeate IIb (P2b) & with 25\% & 98 & 4.26 & 97.93 \\
& protein up & & & \\
\hline
\end{tabular}

